\title{
Myotonic Dystrophy Type 1 Associating Sensitive Polyneuropathy: a Case Report
}

\author{
Elena Florentina MARINGICA', Oana Elisabeta MORARI' , Claudiu Gabriel SOCOLIUC ${ }^{2,3}$, Alexandra \\ Eugenia BASTIAN2,3, Bogdan Ovidiu POPESCU1,4,5
}

\begin{abstract}
Introduction: Myotonic dystrophy (DM) type 1 is a genetic disorder, caused by a trinucleotide CTG repeat expansion in the DMPK gene on chromosome 19. The skeletal muscle is the most severely affected organ, patients clinically presenting weakness and myotonia. Additionally, it may affect other organs, transforming it into a multisystemic disease. The pathophysiological mechanism involves RNA toxicity resulting from the expanded repeat in the mutant DM alleles. Phenotypes of DM1 may be classified as congenital, juvenile, classical or late onset. Case Report: We present the case of a 36-year-old male diagnosed with chronic hepatitis B virus infection 4 years ago, admitted to the Neurology Department for progressive weakness of the distal lower limbs and multiple falls without loss of consciousness due to muscle weakness. Considering the clinical evolution, neurological examination and paraclinical investigations, the patient was diagnosed with myotonic dystrophy type 1 and mild sensitive axonal polyneuropathy of the lower limbs. Conclusion: The diagnosis of DM can be established clinically if the patient has typical manifestations and positive family history. Genetic testing for CTG repeat expansion in the DMPK gene is the gold standard in diagnosing DM1. There is no disease-modifying therapy available for DM yet and management is only symptomatic.
\end{abstract}

Keywords: myotonic dystrophy type 1, myotonia, weakness, sensitive axonal polyneuropathy, genetic testing.

\section{Rezumat}

Introducere: Distrofia miotonică (DM) tip 1 este o boală genetică, cauzată de expansiunea repetițiilor trinucleotidice pe gena DMPK - cromozomul 19. Mușchii scheletici sunt cel mai frecvent afectați, pacienții prezentând scăderea forței musculare și miotonie. În plus, pot fi afectate și alte organe, boala fiind considerată multisistemică. Mecanismul fiziopatologic implică toxicitatea ARN-ului rezultat din expansiunea repetițiilor transcriptului alelelor DM mutante. Fenotipurile DM1 pot fi clasificate: congenital, juvenil, clasic sau cu debut tardiv. Prezentare de caz: Raportăm cazul unui pacient în vârstă de 36 ani, diagnosticat cu infecție cu virus hepatitic B în urmă cu 4 ani, internat pe Secția de Neurologie pentru scădere de forță musculară progresivă la nivelul membrelor inferioare distal și multiple episoade de cădere fără pierderea stării de conștiență, din cauza deficitului motor. Având în vedere evoluția clinică, examenul neurologic și rezultatele investigațiilor paraclinice, pacientul a fost diagnosticat cu distrofie miotonică tip

\footnotetext{
${ }^{1} 2^{\text {nd }}$ Compartment of Neurology, Clinic of Neurology, Colentina Clinical Hospital, Bucharest, Romania

${ }^{2}$ Faculty of Dental Medicine, „Carol Davila" University of Medicine and Pharmacy, Bucharest, Romania

${ }^{3}$ Clinic of Pathology, Colentina Clinical Hospital, Bucharest, Romania

${ }^{4} 6^{\text {th }}$ Department of Clinical Neuroscience, Clinic of Neurology, Colentina Clinical Hospital, „Carol Davila” University of Medicine and Pharmacy, Bucharest, Romania

${ }^{5}$ Laboratory of Molecular Medicine, „Victor Babes" National Institute of Pathology, Bucharest, Romania
}

\section{Corresponding author.}

Elena Florentina MARINGICA, $2^{\text {nd }}$ Compartment of Neurology, Clinic of Neurology, Colentina Clinical Hospital, Bucharest, Romania.

E-mail: elena.maringica@gmail.com 
1 și polineuropatie axonală senzitivă ușoară la membrele inferioare. Concluzie: Diagnosticul de distrofie miotonică poate fi stabilit clinic dacă tabloul clinic și istoricul familial pozitiv sunt sugestive. Testarea genetică pentru expansiunea repetițiilor CTG de pe gena DMPK reprezintă gold standardul pentru confirmarea diagnosticului. Nu există un tratament curativ pentru DM, tratamentul disponibil fiind doar simptomatic.

Cuvinte-cheie: distrofie miotonică tip 1, miotonie, scădere de forță musculară, polineuropatie axonală senzitivă, testare genetică.

\section{INTRODUCTION}

Myotonic dystrophy is a multisystemic autosomal dominant disorder with chronic progression, characterized by affecting the skeletal muscles, ocular lens, heart, lungs, gastrointestinal tract, endocrine glands and central nervous system. The most common manifestations of DM are myotonia, weakness and muscular atrophy. Poor sleep quality, exhaustion and drowsiness have an important effect on the quality of life of these patients. In different studies, the DM mortality rate is estimated 7.3 times higher than that of the normal population, and the average death was 53 years old in one 10-year follow-up study. Most of the cases of mortality in DM are correlated with cardiorespiratory disorders and it is considered that periodically follow-up reduces morbidity and mortality, even though there is no diseasemodifying therapy available $\mathrm{e}^{1-5,11}$.

$\mathrm{DM}$ is an autosomal dominant neuromuscular disease caused by microsatellite expansions. There are two types: DM type 1 (Steinert disease) and DM type 2 (Proximal Myotonic Myopathy - PROMM). DM type 1 is caused by expansion of CTG triplet repeat in the dystrophia myotonica protein kinase (DMPK) gene on chromosome $19 q 13.3$. DM type 2 is caused by the expansion of a CCTG tetramer repeat in ZNF9 (CNBP) gene ${ }^{1-5}$. We report here the case of a 36-year old male diagnosed with DM type 1 , who associated sensitive axonal polyneuropathy of the lower limbs. The confirmation of the diagnosis of DM 1 was made by genetic testing.

\section{CASE REPORT}

A 36-year-old man diagnosed with chronic hepatitis $\mathrm{B}$ virus infection 4 years before presentation (treated with interferon for 1 year) was admitted to the Neurology Department for progressive weakness of the distal lower limbs (mostly in the left ones) and multiple falls from his own level without loss of consciousness, in the context of muscle weakness. On admission, the patient underwent physical examination that revealed sleepy face, frontal baldness, narrowing lower half of the face, prominent zygomatic bones, enophthalmia, lagophthalmia, pale and moist skin, diffuse muscular hypotrophia, steppage gait (mostly on the left), unstable, with small steps, impossible on the tips and heels, intermittent solid dysphagia, bilateral sternocleidomastoid weakness, 4/5 MRC distal brachial motor deficit, bilateral diminished median cubital grip strength, 2/5 MRC distal crural motor deficit, myotonic reaction on the right thenar eminence, globally lost tendon reflexes, absent plantar cutaneous reflexes, generalised hypotonia and diffuse muscular hypotrophia.

Blood tests showed high creatine phosphokinase (565 UI/L), B12 hypovitaminosis $(175.9 \mathrm{pg} / \mathrm{mL})$ and elevated Hbs antigen (4.81 S/N).

Electrocardiogram, echocardiography and spirometry had normal results.

Nerve conduction studies revealed normal motor conduction and mild sensitive axonal neuropathy of the lower limbs (Figure 1).

Electromyography identified myopathic pattern in all examined muscles groups (Figure 2) and myotonic discharges in the left tibialis anterior muscle and flexor carpi ulnaris (Figure 3).

Considering the clinical evolution, neurological examination and paraclinical investigations, the working diagnosis was muscular dystrophy.

We performed an open biopsy from the left gastrocnemius muscle under local anaesthesia. The muscle sample was snap frozen in liquid nitrogen cooled isopentane. Following the muscle orientation, transverse 8 microns thickness cryosections were obtained and stained for examination with standard histology and histochemistry techniques (hematoxylin and eosin HE, Van Gieson, modified Gomori trichrome GT, Sudan BB, periodic acid -Schiff- PAS) and enzyme histochemical preparation for reduced nicotinamide adenine dinucleotide-tetrazolium reductase (NADHTR), succinic dehydrogenase (SDH), lactic dehydrogenase (LDH), myosin adenosine triphosphatase (ATPase) with preincubation at $\mathrm{pH} \mathrm{9.4,} 4.63$ and 4.35. 


\begin{tabular}{|c|c|c|c|c|c|c|c|c|}
\hline Site & \begin{tabular}{|c|c|c|c|} 
Latency \\
$(\mathrm{ms})$
\end{tabular} & Amplitude & Area & Segment & \begin{tabular}{|l|l} 
Datinose \\
(nni)
\end{tabular} & $\begin{array}{c}\text { Interval } \\
\text { (ms) }\end{array}$ & $\begin{array}{l}\mathrm{NCV} \\
(\mathrm{m} / \mathrm{g}) \\
\end{array}$ & NCV ND. \\
\hline \multicolumn{9}{|l|}{ Median, L } \\
\hline \begin{tabular}{|l|} 
Wrist \\
\end{tabular} & $2.94 \mathrm{~ms}$ & $9.200 \mathrm{mV}$ & $25.7 \mathrm{ImVms}$ & Wrist & & $2.94 \mathrm{~mm}$ & & \\
\hline Elbow & $7.00 \mathrm{~ms}$ & $9.580 \mathrm{mV}$ & $24.15 \mathrm{mVms}$ & Wrist - Elbow & $255 \mathrm{~mm}$ & $4.06 \mathrm{~mm}$ & $62.8 \mathrm{~m} / \mathrm{s}$ & \\
\hline \multicolumn{9}{|l|}{ Ulnar, L } \\
\hline Wrist & $2.52 \mathrm{~ms}$ & $6.450 \mathrm{mV}$ & $20.06 \mathrm{mVms}$ & Wrist & & $2.52 \mathrm{~mm}$ & & \\
\hline \multicolumn{9}{|l|}{ Median, R } \\
\hline Wrist & $3.32 \mathrm{~ms}$ & $8.800 \mathrm{mV}$ & $27.53 \mathrm{mVms}$ & Wrist & & $3.32 \mathrm{~mm}$ & & \\
\hline Elbow & $7.24 \mathrm{~ms}$ & $8.080 \mathrm{mV}$ & $23.98 \mathrm{mVms}$ & Wrist - Elbow & $235 \mathrm{~mm}$ & $3.92 \mathrm{~mm}$ & $59.9 \mathrm{~m} / \mathrm{s}$ & \\
\hline \multicolumn{9}{|l|}{ Ulnar, R } \\
\hline Wrist & $2.28 \mathrm{~ms}$ & $8.270 \mathrm{mV}$ & $22.55 \mathrm{mVms}$ & Wrist & & $2.28 \mathrm{~mm}$ & & 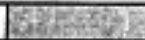 \\
\hline Elbow & $6.58 \mathrm{~ms}$ & $8.040 \mathrm{mV}$ & $22.62 \mathrm{mVms}$ & Wrist - Elbow & $300 \mathrm{~mm}$ & $4.30 \mathrm{~mm}$ & $69.8 \mathrm{~m} / \mathrm{s}$ & 59: \\
\hline \multicolumn{9}{|c|}{ De } \\
\hline Ankle & $3.80 \mathrm{~ms}$ & $4.740 \mathrm{mV}$ & $6.804 \mathrm{mVms}$ & Ankle & & $3.80 \mathrm{~mm}$ & & Fis \\
\hline \multicolumn{9}{|c|}{ 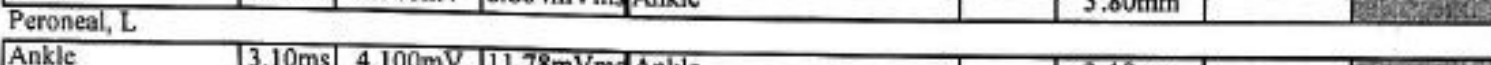 } \\
\hline Ankle & $3.10 \mathrm{~ms}$ & $4.100 \mathrm{mV}$ & $11.78 \mathrm{mVms}$ & Ankle & & $3.10 \mathrm{~mm}$ & & $\sqrt{528}$ \\
\hline Head of fibula & $10.75 \mathrm{~ms}$ & $3.320 \mathrm{mV}$ & $11.05 \mathrm{mVms}$ & Ankle - Head of fibula & $345 \mathrm{~mm}$ & $7.65 \mathrm{~mm}$ & $45.1 \mathrm{~m} / \mathrm{s}$ & \\
\hline Popliteal TA & $3.25 \mathrm{~ms}$ & $2.400 \mathrm{mV}$ & $17.01 \mathrm{mVms}$ & Head of fibula - Popliteal TA & & $7.50 \mathrm{~mm}$ & & PEses \\
\hline \multicolumn{9}{|c|}{ 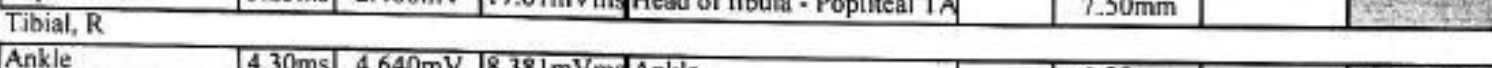 } \\
\hline \begin{tabular}{|l|l|} 
Ankle \\
\end{tabular} & $4.30 \mathrm{~ms}$ & $4.640 \mathrm{mV}$ & $8.381 \mathrm{mVms}$ & Ankle & & $4.30 \mathrm{~mm}$ & & Exe \\
\hline \multicolumn{9}{|c|}{ 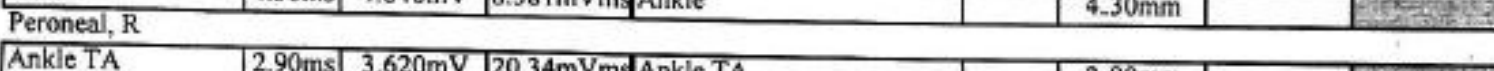 } \\
\hline Ankle TA & $2,90 \mathrm{~ms}$ & $3.620 \mathrm{mV}$ & $20.34 \mathrm{mVms}$ & Ankle TA & & $2.90 \mathrm{~mm}$ & & Exis \\
\hline Fead of fibula & $4.45 \mathrm{~ms}$ & $3.390 \mathrm{mV}$ & $19.31 \mathrm{mVms}$ & Ankle TA - Head of fibula & $80 \mathrm{~mm}$ & $1.55 \mathrm{~mm}$ & $51.6 \mathrm{~m} / \mathrm{s}$ & 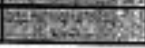 \\
\hline \multicolumn{9}{|c|}{ Sensory Nerve Conduction Study } \\
\hline \begin{tabular}{|r|}
\multicolumn{2}{|c|}{ Site } \\
Median, L
\end{tabular} & \begin{tabular}{|c|}
$\begin{array}{c}\text { Latengy } \\
\text { (ms) }\end{array}$ \\
\end{tabular} & Ainplitude & Area & Segment & $\begin{array}{c}\text { Datesce } \\
(\mathrm{mm})\end{array}$ & $\begin{array}{c}\text { Interval } \\
\text { (ms) }\end{array}$ & $\begin{array}{l}\text { NCV } \\
(\mathrm{m} / \mathrm{s})\end{array}$ & NCV \\
\hline \multicolumn{9}{|l|}{$\begin{array}{l}\text { Median, L } \\
\text { Wrist }\end{array}$} \\
\hline \begin{tabular}{|l} 
Wrist \\
Ulnar, L
\end{tabular} & $3.76 \mathrm{~ms}$ & $24 u V$ & $0.144 \mathrm{u} V \mathrm{~ms}$ & Wrist & $160 \mathrm{~mm}$ & $3.76 \mathrm{~mm}$ & $50 \mathrm{~m} / \mathrm{s}$ & FII \\
\hline \multicolumn{9}{|l|}{$\begin{array}{l}\text { Ulnar, L } \\
\text { Wrist }\end{array}$} \\
\hline \begin{tabular}{|l|} 
Wrist \\
Median, R
\end{tabular} & $2.12 \mathrm{~ms}$ & $32 \mathrm{uV}$ & $0.581 \mathrm{lums}$ & Wrist & $130 \mathrm{~mm}$ & $2.12 \mathrm{~mm}$ & $61.3 \mathrm{~m} / \mathrm{s}$ & 78. \\
\hline \multicolumn{9}{|c|}{ 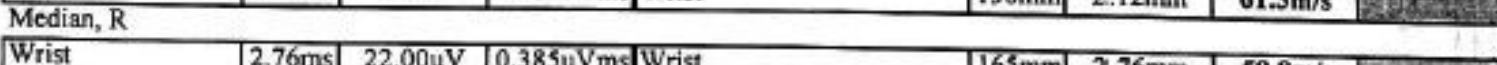 } \\
\hline Wrist & $2.76 \mathrm{~ms}$ & $22.00 \mathrm{uV}$ & $0.385 \mathrm{umm}$ & Wrist & $165 \mathrm{~mm}$ & $2.76 \mathrm{~mm}$ & $59.8 \mathrm{~m} / \mathrm{s}$ & 25: \\
\hline Elbow & $2.80 \mathrm{~ms}$ & & $0.301 \mathrm{uVms}$ & Wrist - Elbow & & $0.04 \mathrm{~mm}$ & & $80 \%$ \\
\hline \multicolumn{9}{|c|}{ 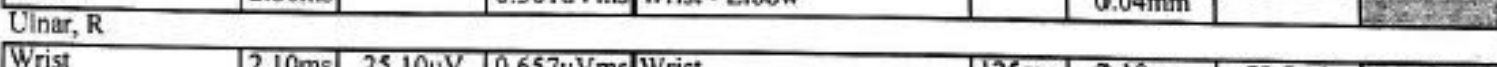 } \\
\hline Wrist & $2.10 \mathrm{~ms}$ & $25.10 \mathrm{uV}$ & $0.657 \mathrm{uVms}$ & Wrist & $125 \mathrm{~mm}$ & $2.10 \mathrm{~mm}$ & $59.5 \mathrm{~m} / \mathrm{s}$ & $\overline{7}=1$ \\
\hline \multicolumn{9}{|c|}{ 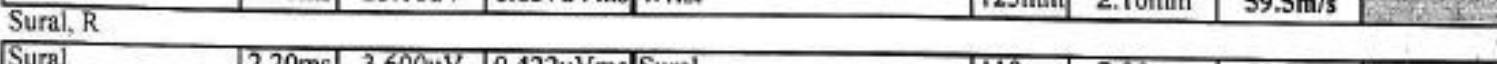 } \\
\hline Sural & $2,20 \mathrm{~ms}$ & $3.600 \mathrm{uV}$ & $0.422 \mathrm{uVms}$ & Sural & $110 \mathrm{~mm}$ & $2.20 \mathrm{~mm}$ & $50.0 \mathrm{~m} / \mathrm{s}$ & F" \\
\hline \multicolumn{9}{|c|}{ Superficial Peroneal, $\mathrm{R}$} \\
\hline peronier superf & $2.72 \mathrm{~ms}$ & $5.000 \mathrm{uV}$ & $0,388 \mathrm{uVms}$ & peronier superf & $140 \mathrm{~mm}$ & $2.72 m$ & $51.5 \mathrm{~m} / 3$ & प्रूप: \\
\hline \multicolumn{9}{|c|}{ Superficial Peroneal, L } \\
\hline peronier superf & $2.76 \mathrm{~ms}$ & $4.700 \mathrm{uV}$ & $0.125 \mathrm{uVms}$ & peronier superf & $130 \mathrm{~mm}$ & $2,76 \mathrm{~mm}$ & $47.1 \mathrm{~m} / \mathrm{s}$ & Fise \\
\hline
\end{tabular}

Figure 1. Nerve conduction studies showing normal motor conduction and mild sensitive axonal neuropathy of the lower limbs.

The skeletal muscle fragment presented well preserved architecture, marked variation in myofiber size, some groups of 2-8 muscular fibers with moderate and severe atrophy, many fibers with one or more internal nuclei, especially the atrophic fibers. Type 1 fibers atrophy and type 2 fibers hypertrophy is observed. Internal structure of the fibers is normal (Figure 4, Figure 5.1-5.2). In conclusion, the morphological muscular changes are compatible, in the clinical and paraclinical context, with myotonic dystrophy type 1 .
Furthermore, it was considered necessary to make genetic testing - the relevant region of DMPK gene was analysed by polymerase chain reaction (PCR) and capillary electrophoresis on a DNA sequencing system for an expansion of the CTG trinucleotide repeat region. To exclude large expansions that cannot be identified by standard fragment length analysis a triplet repeat primed PCR (TP-PCR) was carried out. The TP-PCR revealed a large CTG trinucleotide repeat expansion $>50$ repeats in the second allele. The result 


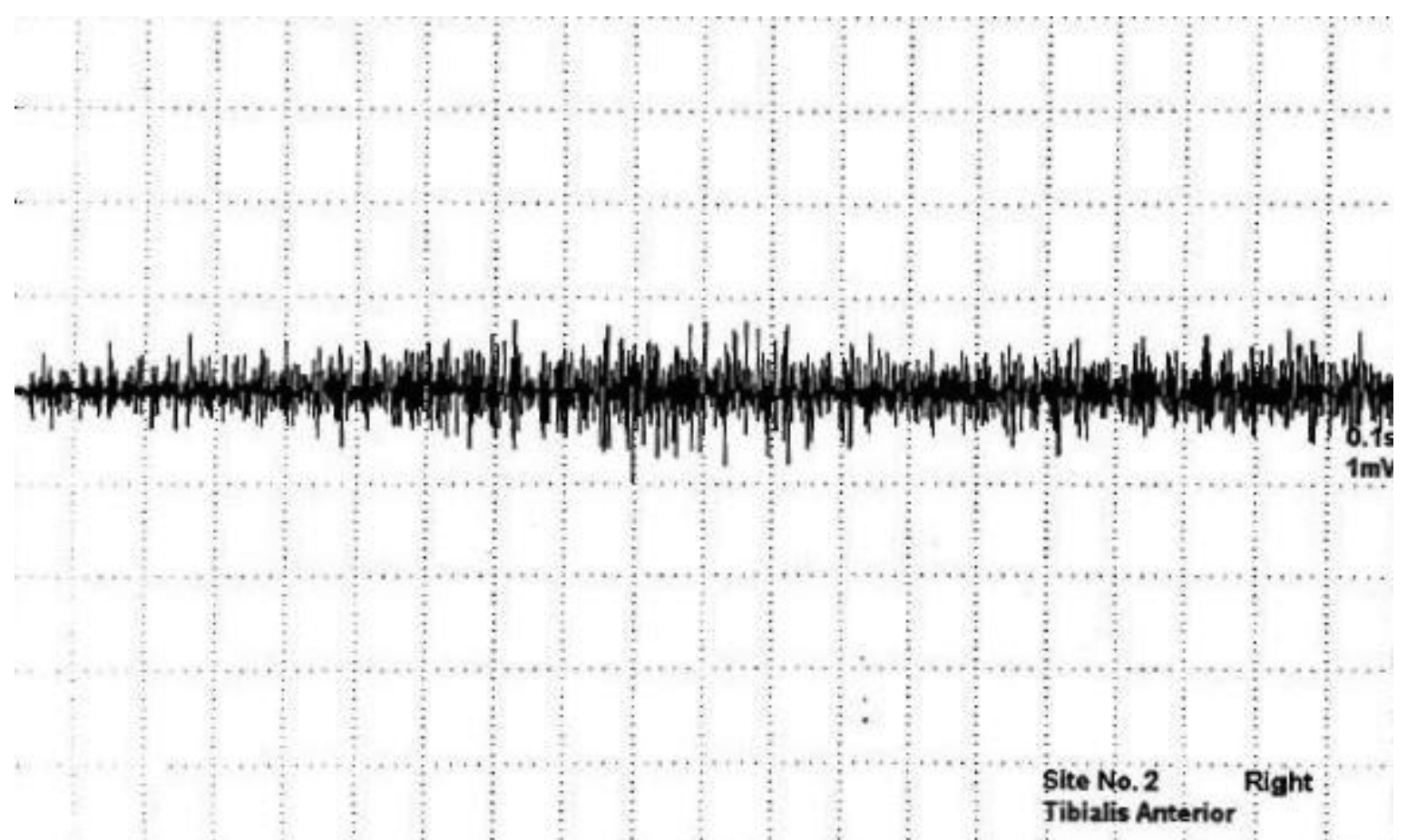

Figure 2. Myopathic recruitment pattern in all examined group muscles, including right tibialis anterior, vastus lateralis, extensor digitorum communis, flexor carpi ulnaris.

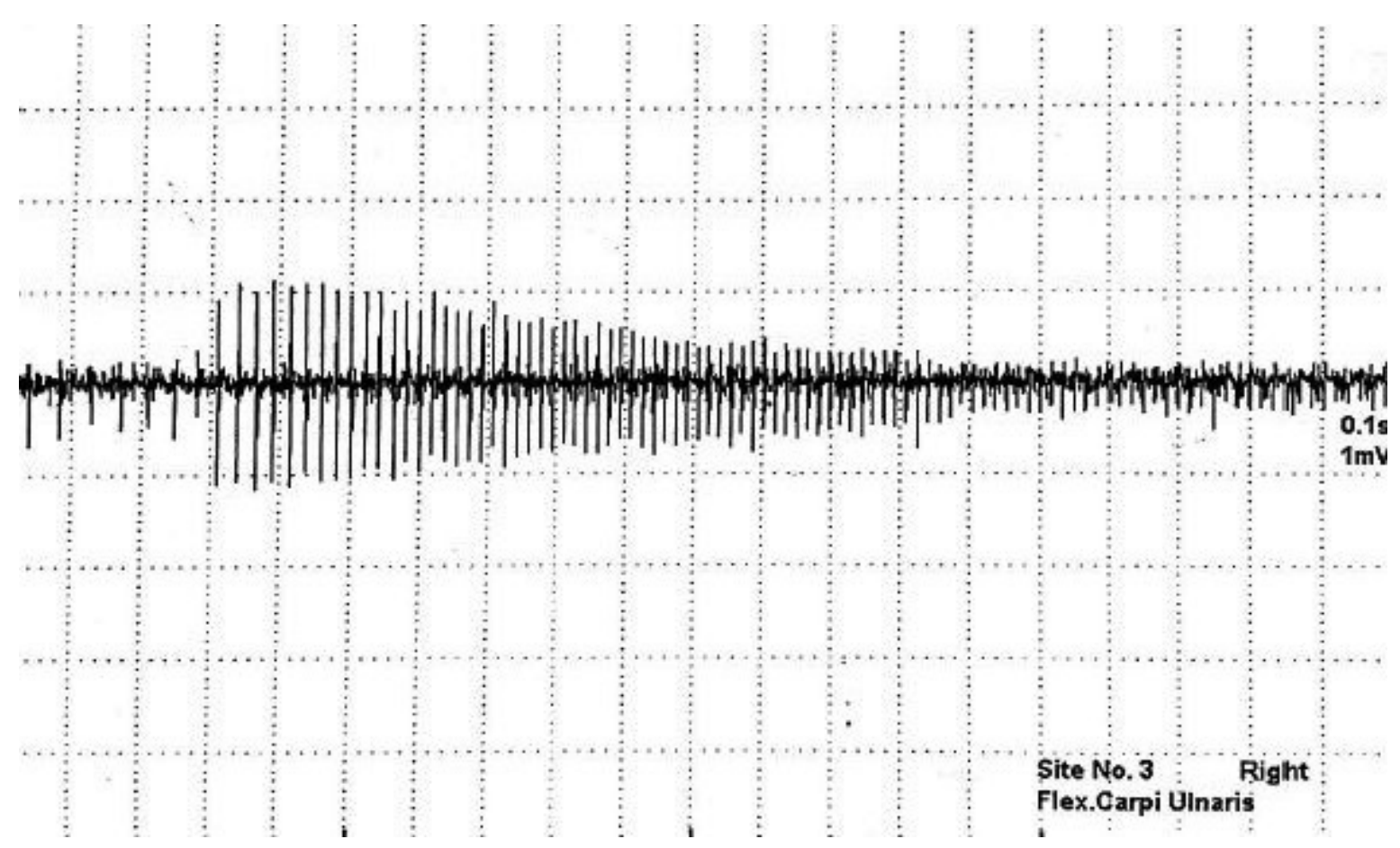

Figure 3. Electrical myotonia in right flexor carpi ulnaris. 

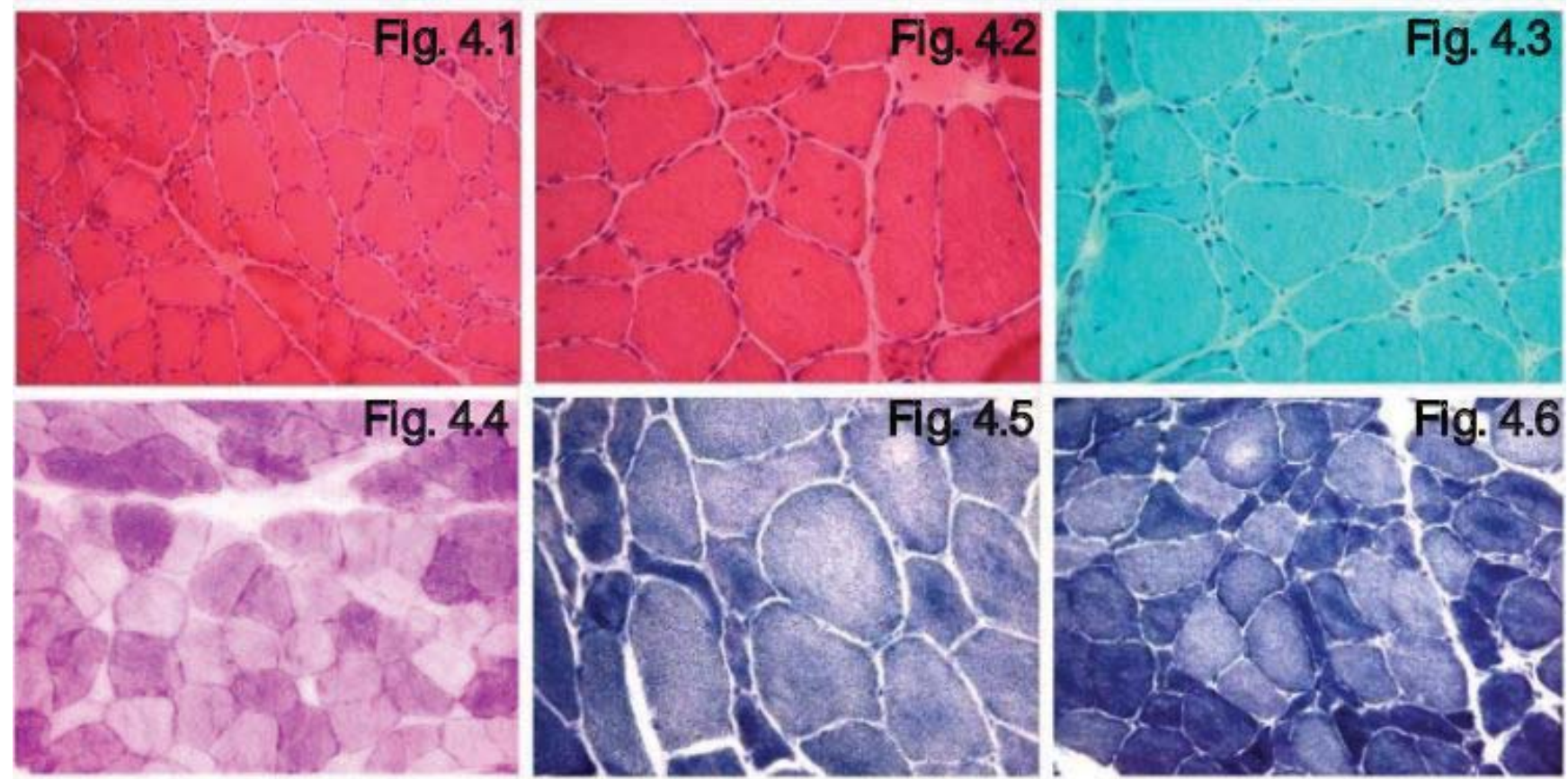

Figure 4. Myopathic changes of the muscle, with marked variation in the fiber size and shape, both atrophic angulated and hypertrophic fibers and increased number of internal nuclei. Figure 4.1, 4.2 - HE; Figure 4.3 - modified Gomori trichrome - GT; Figure 4.4 - PAS; Figure 4.5 - NADH-TR; Figure 4.6 - LDH.
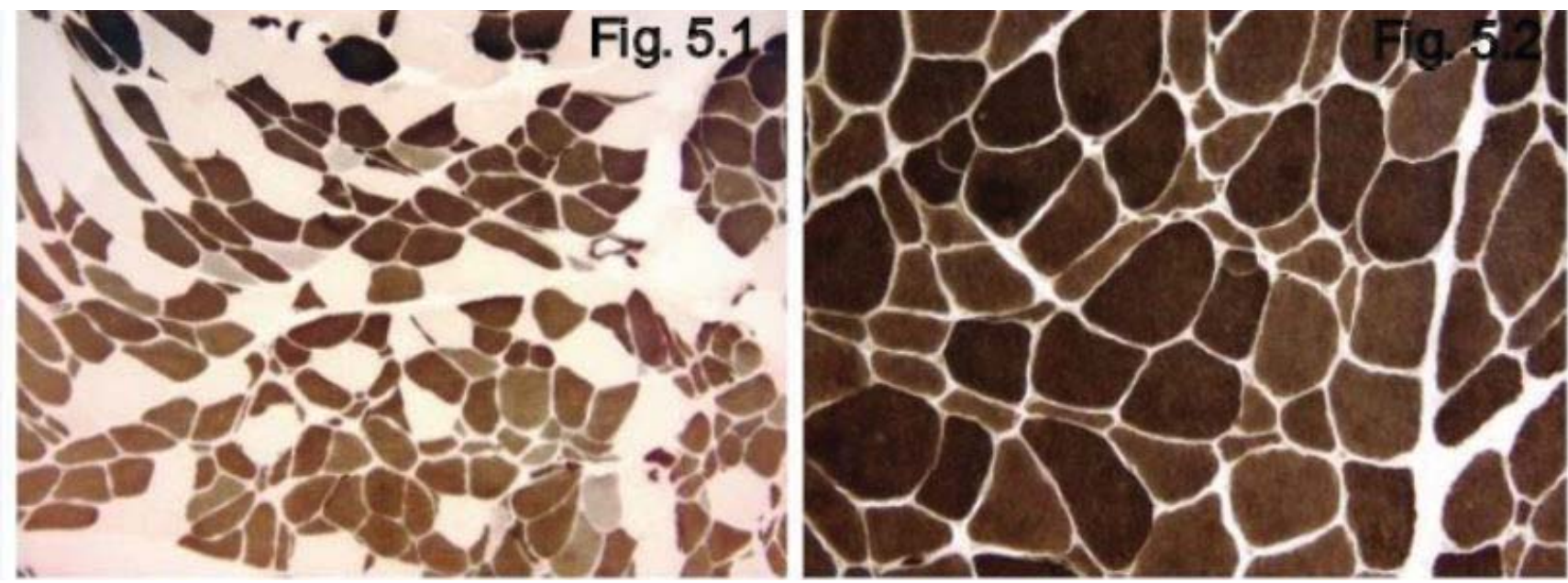

Figure 5.1. Myosin ATPase staining with preincubation at $\mathrm{pH} 4.35$ and 4.63 revealing a disparity between the size of darkly stained type 1 fibers and lightly stained type 2 fibers, with atrophy of type 1, hypertrophy of type 2 fibers of both subtypes and type 1 fiber predominance. Internal nuclei are mainly seen in type 1 fibers.

Figure 5.2. Myosin ATPase staining with preincubation at pH 9,4 showing hypertrophy of type 2 fibers (dark) and atrophy of type 1 fibers (light).

of the genetic analysis was consistent with DM type 1, so the patient was diagnosed with myotonic dystrophy type 1 (Steinert disease).

Also, an ophthalmologic evaluation documented the diagnosis of both eyes cataracts.
The patient was treated with vitamins B1, B6 and B12, intramuscular administration - 1 vial/ day for 1 week, then $1 \mathrm{vial} /$ week for $2-5$ weeks, then 1 vial/ month until vitamin B12 seric level would have normalised and the patient was recommended to wear 
molded ankle-foot orthoses to prevent foot-drop and enhance gait stability. Over a 6-month follow-up period, the patient experienced a light improvement in muscular function, at the physical examination the tendon reflexes were diminished, the B12 vitamin blood level was normal and the electroneurography showed physiological motor and sensitive conduction.

\section{DISCUSSION}

DM type 1 is the most common hereditary neuromuscular disorder among European adults. It is characterized by skeletal and smooth muscle affection, with progressive myopathy, myotonia and the involvement of multiple organs, as the endocrine glands and central nervous system. The pathogenesis of DM type 1 is considered to be produced by the expansion of the CTG trinucleotidic repeat in the DMPK gene (chromosome 19). The CTG triplet repeat expansion in the DMPK gene could determine nuclear localization of mutant mRNA. Toxic repeat RNA sequences could be responsible for the alteration of the normal expression of genes and the splicing process and may determine the abnormal expression of neuromuscular proteins. Clinical manifestations can be myotonia, skeletal and respiratory weakness, hypotrophia, cardiac arrhythmias, cataracts and insulin resistance ${ }^{1-5}$.

DM 1 is classified into four phenotypes: congenital, childhood, adult and mild phenotypes. The prognosis of DM type 1 is correlated with the age of onset. $\mathrm{Pa}^{-}$ tients with childhood-onset DM have higher mortality proportions, while patients with adult-onset DM typically have a more favorable prognosis. Adult-onset DM type 1 is the most prevalent form of DM 1 . The main clinical manifestations include muscle weakness, myotonia and hypotrophia of the skeletal muscles. Most patients present myotonia, clinically manifest as a difficulty in actively relaxing the thumb or fingers after active contraction. The hypotrophia initially affects the hand and the forearm muscles and then progresses to the head and facial muscles. Myotonia can be present simultaneously with hypotrophia or can precede it by a few years ${ }^{1-5}$.

Among other organs affection, gastrointestinal peristalsis can be abnormal and affect rectum peristalsis, leading to spasmodic colic and delayed emptying of the gallbladder, leading to cholelithiasis ${ }^{1-7}$.

Endocrinologic involvement can determine alopecia, glucose intolerance, genital hypoplasia and sexual dysfunction. The most common dystrophic change in non-muscular tissues is lenticular opacities ${ }^{1-7}$.
Developmental cognitive delay could occur; in later adult life, some patients tend to be skeptical, inattentive or argumentative ${ }^{1,5}$.

Diagnosis of DM type 1 is determined by clinical manifestations, family history, electromyography, muscle biopsy, but genetic testing remains the gold stan$\operatorname{dard}^{1-3}$. In this case report, the patient presented skeletal distal weakness but also sensitive polyneuropathy which initially obscured diagnosis. The etiology of the sensitive polyneuropathy could have been the B12 vitamin deficiency or the interferon administration for hepatitis B virus infection. Furthermore, the patient was directed to the Hematology Department for complete Biermer anemia evaluation (peripheral blood smear, folate acid level dosing, autoantibodies to intrinsic factor, response to B12 vitamin replacement, superior digestive endoscopy with gastric mucosa biopsy).

Otherwise, peripheral nerve involvement may be one of the multisystemic manifestations of DM type 1 , but is usually subclinical and independent of glucose intolerance (the presence of diabetes was not related to abnormal nerve conduction). Some studies sustain that most abnormal ENG results in DM type 1 patients are more likely to result from myopathic changes, coincidental neuropathies or radiculopathies than from primary involvement of the nerve ${ }^{8,9}$.

In the differential diagnosis of DM type 1 , it is essential to exclude other non dystrophic myopathies as myotonia congenita (which is typically associated with hypermyotrophy), hyperkalemic periodic paralysis, paramyotonia, adult-onset acid maltase deficiency or chronic denervating disorders, polymyositis, inclusion body myositis, toxic myopathies (associated with statins, clofibrate, chloroquine, colchicine) or distal myopathies (without myotonia) such as hereditary inclusion body myopathy, Welander distal myopathy or limb-girdle muscular dystrophy types $2 \mathrm{~B}$ and $2 \mathrm{~L}$. These disorders can be distinguished from DM by clinical manifestations, muscle biopsy results and genetic analysis ${ }^{2,5}$.

The patient presented in this case report was suspected of DM regarding the clinical presentation, the physical examination findings and the results of the EMG and muscular biopsy, but the diagnosis of DM type 1 was confirmed by the genetic testing.

Most patients with DM may need cardiac evaluations for arrhythmia and cardiomyopathy, spirometry, polysomnography, ophthalmologic examination for cataracts, swallowing assessment and endocrine testing ${ }^{2,3,5}$. 
Only symptomatic therapies are available for patients with DM type 1 . For patients accusing severe myotonia, therapy with mexiletine 450 or $600 \mathrm{mg}$ daily should be administered. Cardiac and respiratory dysfunctions are the most important causes of mortality in patients with DM type 1, therefore periodically cardiologic evaluation and spirometry must be performed. Associated cataracts treatment is surgical. ${ }^{2,3,5,10}$

Development in the studying of the molecular mechanisms in the pathophysiology of myotonic dystrophy have brought to light possible new gene therapies to manage genetic disorders like dystrophic myotonia ${ }^{5,10}$.

\section{CONCLUSION}

The diagnosis of DM can generally be established clinically if the patient has typical manifestations and a

\section{References}

1. A.H. Ropper, M.A. Samuels, J.P. Klein. Adams and Victor's Principles of Neurology, tenth edition, 1407:1466, 1490:1504.

2. Basil T Darras, MD. Myotonic dystrophy: Etiology, clinical features, and diagnosis, Aug 20, 2019. Available from: https://www. uptodate.com/contents/myotonic-dystrophy-etiology-clinicalfeatures-and-diagnosis?topicRef $=5140 \&$ source=see_link

3. Basil T Darras, MD. Myotonic dystrophy: Treatment and prognosis, May 21, 2019. Available from: https://www.uptodate.com/ contents/myotonic-dystrophy-treatment-and-prognosis?topic Ref $=5147 \&$ source=see_link

4. Finsterer J, Rudnik-Schöneborn S. Myotonic dystrophies: Clinical presentation, pathogenesis, diagnostics and therapy. Fortschr Neurol Psychiatr. 2015;83:9 17. doi: 10.1055/s-00341385734. (In German)

5. Chunrong Li, Xiaoling Zhang, Chunkui Zhou, Lijun Zhu, Kangding Liu and Shaokuan Fang. Dystrophia myotonica type 1 presenting with dysarthria: A case report and literature review. Exp Ther Med. 2017 Aug; 14(2): 1104-1108. Published online 2017 Jun 12. doi: 10.3892/etm.2017.4579

6. Turner C, Hilton-Jones D. Myotonic dystrophy: Diagnosis, management and new therapies. Curr Opin Neurol. 2014;27:599606. doi: 10.1097/WC0.0000000000000128 positive family history. Genetic testing for CTG repeat expansion in the dystrophia myotonica protein kinase gene is considered the gold standard in diagnosing myotonic dystrophy type 1 . Electromyography will usually demonstrate the presence of myotonia if this has not been found clinically or if uncertainty persists regarding its presence or absence on examination. There is no disease-modifying therapy available for the treatment of DM yet, but future gene therapies targets to treat genetic disorders like myotonic dystrophy.

Compliance with ethics requirements: The authors declare no conflict of interest regarding this article. The authors declare that all the procedures and experiments of this study respect the ethical standards in the Helsinki Declaration of 1975, as revised in 2008(5), as well as the national law. Informed consent was obtained from all the patients included in the study.

7. Groh WJ, Groh MR, Saha C, Kincaid JC, Simmons Z, Ciafaloni E, Pourmand R, Otten RF, Bhakta D, Nair GV, et al. Electrocardiographic abnormalities and sudden death in myotonic dystrophy type 1. N Engl J Med. 2008;358:2688-2697. doi: 10.1056/NEJMoa062800

8. Hermans MC, Faber CG, Vanhoutte EK, Bakkers M, De Baets $\mathrm{MH}$, de Die-Smulders CE, Merkies IS. Peripheral neuropathy in myotonic dystrophy type 1. J Peripher Nerv Syst. 2011 Mar;16(1):24-9. doi: 10.1111/j.1529-8027.2011.00313.x.

9. Bae JS1, Kim OK, Kim SJ, Kim BJ. Abnormalities of nerve conduction studies in myotonic dystrophy type 1: primary involvement of nerves or incidental coexistence? J Clin Neurosci. 2008 Oct;15(10):1120-4. doi: 10.1016/j.jocn.2007.11.002.

10. Smith CA, Gutmann L. Myotonic dystrophy type 1 management and therapeutics. Curr Treat Options Neurol. 2016;18:52. doi: 10.1007/s11940-016-0434-1

11. Mathieu J, Allard P, Potvin L, Prévost C, Bégin P. A 10-year study of mortality in a cohort of patients with myotonic dystrophy. Neurology. 1999;52:1658-1662. doi: 10.1212/WNL.52.8.1658. 
